\title{
A GCM comparison of Pleistocene super-interglacial periods in relation to Lake El'gygytgyn, NE Arctic Russia
}

\author{
A. J. Coletti ${ }^{1}$, R. M. DeConto ${ }^{1}$, J. Brigham-Grette ${ }^{1}$, and M. Melles ${ }^{2}$ \\ ${ }^{1}$ Department of Geosciences, University of Massachusetts, Amherst, MA 01003, USA \\ ${ }^{2}$ Institute of Geology and Mineralogy, University of Cologne, Zülpicher Strasse 49a, 50674 Cologne, Germany \\ Correspondence to: A. J. Coletti (ajcolett@geo.umass.edu)
}

Received: 20 June 2014 - Published in Clim. Past Discuss.: 07 August 2014

Revised: 03 June 2015 - Accepted: 14 June 2015 - Published: 10 July 2015

\begin{abstract}
Until now, the lack of time-continuous, terrestrial paleoenvironmental data from the Pleistocene Arctic has made model simulations of past interglacials difficult to assess. Here, we compare climate simulations of four warm interglacials at Marine Isotope Stages (MISs) 1 (9 ka), 5e (127 ka), 11c (409 ka) and 31 (1072 ka) with new proxy climate data recovered from Lake El'gygytgyn, NE Russia. Climate reconstructions of the mean temperature of the warmest month (MTWM) indicate conditions up to 0.4, 2.1, 0.5 and $3.1^{\circ} \mathrm{C}$ warmer than today during MIS $1,5 \mathrm{e}, 11 \mathrm{c}$ and 31 , respectively. While the climate model captures much of the observed warming during each interglacial, largely in response to boreal summer (JJA) orbital forcing, the extraordinary warmth of MIS 11c compared to the other interglacials in the Lake El'gygytgyn temperature proxy reconstructions remains difficult to explain. To deconvolve the contribution of multiple influences on interglacial warming at Lake El'gygytgyn, we isolated the influence of vegetation, sea ice and circum-Arctic land ice feedbacks on the modeled climate of the Beringian interior. Simulations accounting for climate-vegetation-land-surface feedbacks during all four interglacials show expanding boreal forest cover with increasing summer insolation intensity. A deglaciated Greenland is shown to have a minimal effect on northeast Asian temperature during the warmth of stages $11 \mathrm{c}$ and 31 (Melles et al., 2012). A prescribed enhancement of oceanic heat transport into the Arctic Ocean does have some effect on Lake El'gygytgyn's regional climate, but the exceptional warmth of MIS 11c remains enigmatic compared to the modest orbital and greenhouse gas forcing during that interglacial.
\end{abstract}

\section{Introduction}

Knowledge of Pleistocene climate history has increased dramatically over the past 3 decades; however, existing records remain strongly biased toward an oceanic viewpoint due to the lack of long terrestrial archives. In the context of future warming, it is clearly important to understand the effects of warming on the terrestrial Arctic, the strength of polar amplification and systemic teleconnections to and from other latitudes. Past warm periods known as interglacials, over the past 2.8 million years, provide a means of studying climates warmer than today.

In 2009, a multinational team drilled a sediment core from a $25 \mathrm{~km}$ wide impact crater lake known as Lake El'gygytgyn (hereafter, "Lake E"), in northeast Siberia (Brigham-Grette et al., 2013; Melles et al., 2012). The core contains the longest Arctic terrestrial record ever recovered, extending back $\sim 3.5$ million years, and provides evidence for periods of exceptional warmth during Pleistocene interglacials as defined by marine benthic $\delta^{18} \mathrm{O}$ records (Lisiecki and Raymo, 2005) (Fig. 1a and b). It has been shown that Marine Isotope Stages $1,5 \mathrm{e}, 11 \mathrm{c}$ and 31 were among the warmest interglacials in the Pleistocene Arctic (Melles et al., 2012).

To explore the sensitivity of northwestern Beringia to interglacial forcing and the mechanisms responsible for the observed climate changes, we use a global climate model coupled to an interactive vegetation model to simulate the terrestrial Arctic's response to the greenhouse gas and astronomical forcing associated with specific interglacials (e.g., Yin and Berger, 2011). A range of sensitivity tests were performed and changes in boundary conditions were imposed to test the response of the region to changes in circum-Arctic 

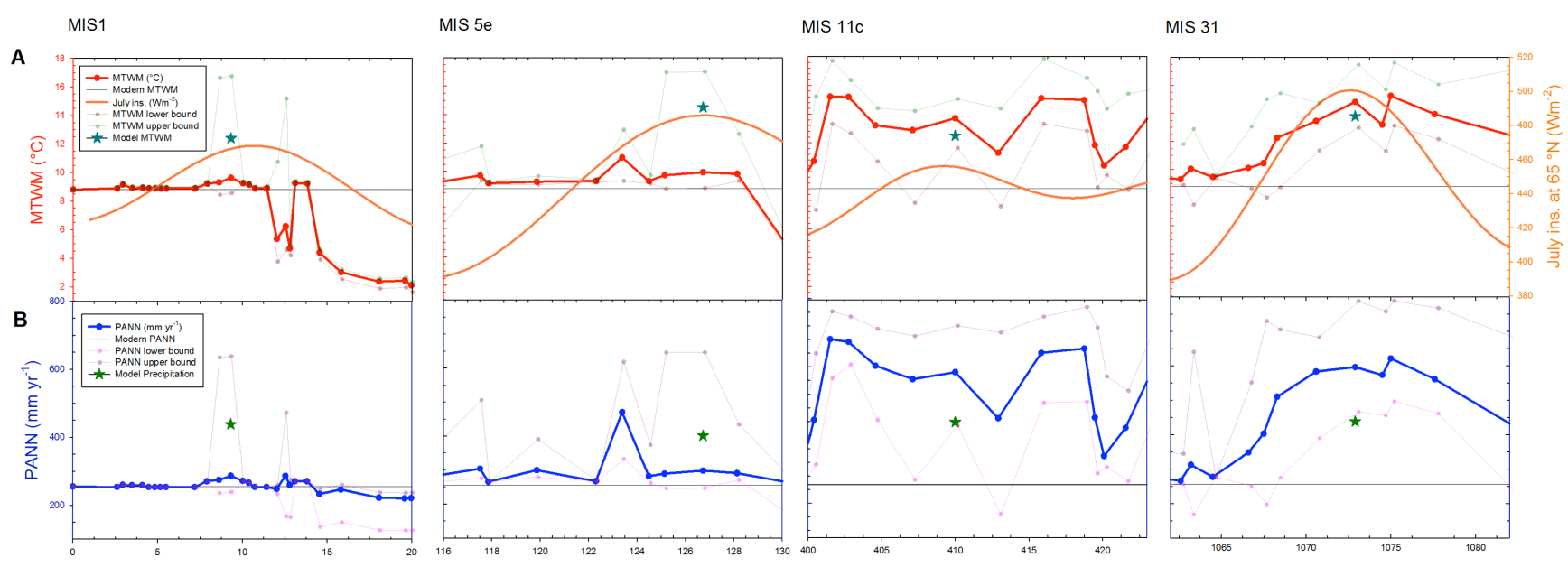

Age (ka)

Figure 1. Reconstructed MTWM (a) and PANN (b) from Melles et al. (2012). Transparent data above and below the bold lines are upper and lower limits of each data point calculated from a best modern analogue technique (MAT) function. The dark cyan (in a) and dark green (in b) stars denote results from the GCM simulations with respect to MTWM and PANN.

ice sheets and possible changes in ocean heat transport into the Arctic Ocean. In this paper, we will outline changes in radiative forcing attributed to orbital changes while also outlining changes in temperature, precipitation and vegetation in detail, assumed to also be related to these changes. The results are then compared to the Lake E multi-proxy reconstructions.

\section{Model and experimental design}

All global climate simulations discussed herein were performed using the current version of the Global ENvironmental and Ecological Simulation of Interactive Systems (GENESIS) global climate model (GCM) version 3.0 (Alder et al., 2011; Thompson and Pollard, 1997). GENESIS is an atmosphere, land surface, ocean, snow, sea ice, ice sheet and vegetation coupled model. As used here, spectral resolution of the atmosphere GCM is a T31 resolution (approximately $3.75^{\circ}$ resolution) with 18 vertical levels (Thompson and Pollard, 1997). The AGCM (atmospheric global climate model) is coupled to $2^{\circ} \times 2^{\circ}$ soil, snow, vegetation, ocean and sea ice model components. The GCM is interactively coupled to the BIOME4 (Kaplan, 2003) vegetation model that predicts equilibrium vegetation distribution, structure and biogeochemistry using monthly mean climatologies of precipitation, temperature and clouds simulated by the GCM. Vegetation distributions take the form of 27 plant biomes, including 12 plant functional types (PFTs) that represent broad, physiologically distinct classes (Kaplan, 2003). GENESIS includes options for coupling to an ocean general circulation model (Alder et al., 2011) or a non-dynamical, slab ocean model that incorporates heat transfer, calculations of sea surface temperatures (SSTs) and feedbacks operating be- tween ocean surface and sea ice. The slab mixed-layer ocean model is used here to allow multiple simulations to be performed with and without imposed perturbations of surface ocean conditions. This version of the GCM has a sensitivity of $2.9^{\circ} \mathrm{C}$, without GHG (greenhouse gas), vegetation or ice sheet feedbacks. Greenhouse gases and orbital parameters for each interglacial simulation were prescribed according to ice core records (Loulergue et al., 2008; Lüthi et al., 2008; Schilt et al., 2010) and standard astronomical solutions (Berger, 1978).

The strategy adopted here was to target Marine Isotope Stages (MISs) 1 (11 ka), 5e (127 ka), 11c (409 ka) and 31 $(1072 \mathrm{ka})$, corresponding to the timing of peak summer (July) warmth observed at Lake E and identified as "superinterglacials" by Melles et al. (2012). Equilibrium simulations were performed at the time of peak boreal summer insolation at $67.5^{\circ} \mathrm{N}$ (Berger, 1978), assuming the real climate system equilibrated within a half-precession cycle. Model temperature and precipitation values were calculated from 20-year averages taken from the 60- to 80-year equilibrated simulations. Preliminary analysis of pollen assemblages in the Lake E core is assumed to provide a record of peak summer temperatures; hence, our data-model comparisons focus on the warmest monthly mean climate (July). A simulation of preindustrial climate (280 ppmv $p \mathrm{CO}_{2}$ ) was run as a control experiment to evaluate the model's representation of Beringian climate and to provide a baseline for comparing super-interglacial simulations. A modern Greenland Ice Sheet (GIS) was prescribed unless otherwise noted. In simulations without a GIS, the ice sheet was replaced with icefree, isostatically equilibrated land-surface elevations. 


\subsection{MIS 1, $9 \mathrm{ka}$}

MIS 1 represents the last $\sim 11000$ years and its onset roughly coincides with the end of the Younger Dryas $(\sim 11500$ years BP). Peak boreal summer insolation occurs at $\sim 9 \mathrm{ka}$, when summer insolation was $\sim 510 \mathrm{~W} \mathrm{~m}^{-2}$ at $65^{\circ} \mathrm{N}$, compared to $446 \mathrm{~W} \mathrm{~m}^{-2}$ today. Proxy indicators suggest conditions were warmer than in the present $\left(+1.6^{\circ} \mathrm{C}\right.$ over the western Arctic and +2 to $4{ }^{\circ} \mathrm{C}$ in the circum-Arctic), with lush birch and alder shrubs (Melles et al., 2012) dominating the vegetation around the lake. This period, known as the Holocene Climate Optimum (HCO), was spatially variable, with most warming in the high latitudes and minimal warming in the midlatitudes and tropics (Kitoh and Murakami, 2002).

\subsection{MIS 5e, $127 \mathrm{ka}$}

MIS 5e, also known as the last interglaciation (LIG), is one of the warmest interglacials of the Pleistocene and lasted roughly $\sim 14 \mathrm{kyr}$ (130 to $116 \mathrm{ka}$ ). High obliquity, eccentricity and the timing of perihelion (precession) combined to produce high-intensity boreal summer insolation at around $127 \mathrm{ka}$. Greenland ice core records (Dahl-Jensen and NEEM community members, 2013) suggest summer warming of up to $8 \pm 4^{\circ} \mathrm{C}$ over northeast Greenland but only a modest reduction in the size of the Greenland Ice Sheet (GIS). Studies involving $\mathrm{Sr}-\mathrm{Nd}-\mathrm{Pb}$ isotope ratios of silt-sized sediment discharged from southern Greenland suggest that no single southern Greenland geologic terrain was completely deglaciated during the LIG; however, some southern GIS retreat was evident (Colville et al., 2011). A previous model study of MIS 5e by Yin and Berger (2011) involved running a model of intermediate complexity to test relative contributions of GHG and insolation forcing on LIG warmth. They found that GHGs play a dominant role in the variations of the annual mean temperature of both the globe and the southern high latitudes, whereas insolation plays a dominant role in precipitation, northern high-latitude temperatures and sea ice extent (Yin and Berger, 2011). Similarly, model simulations have shown that insolation anomalies during MIS 5e likely caused significant summer (JJA) warming throughout the Arctic (Bakker et al., 2013; Lunt et al., 2013; OttoBliesner et al., 2006).

The LIG simulation shown here was used to compare paleoenvironmental conditions in western Beringia, including temperature, vegetation and precipitation, to Lake E pollen proxy analysis. Orbital parameters and greenhouse gas concentrations were set at their $127 \mathrm{ka}$ values to represent peak boreal warmth during MIS $5 \mathrm{e}$.

\subsection{MIS 11c, $409 \mathrm{ka}$}

MIS 11c is another exceptionally warm interglacial (Howard, 1997 ) that lasted from 428 to $383 \mathrm{ka}$ ( $\sim 45 \mathrm{kyr}$ ). Sediment records from the Arctic containing information on MIS 11 are generally lacking (Miller et al., 2010b). Unlike the other interglacials, MIS 11c was remarkably long, with two boreal insolation maxima at $\sim 409$ and $423 \mathrm{ka}$, creating extensive warmth throughout the Arctic (Melles et al., 2012). Unlike MIS 5e, there is evidence that the GIS may have been reduced in size (Raymo and Mitrovica, 2012; Willerslev et al., 2007), with lush boreal forest covering most of southern Greenland (de Vernal and Hillaire-Marcel, 2008). Particularly warm conditions are also suggested by pollen records analyzed from Lake Biwa (Tarasov et al., 2011), located in Shiga Prefecture, Japan. Likewise, a study from Lake Baikal also indicates warmer than modern temperatures, with a "conifer optimum" suggesting warmer conditions and less aridity, perhaps influenced by higher sea levels and reduced continentality (Prokopenko et al., 2010).

Three different simulations (see Tables 1 and 2) were run to test the sensitivity of the lake region to MIS-11c forcing. The first simulation used default boundary conditions, including a modern GIS (MIS11GIS). The second simulation tested the sensitivity of the Lake E region to an ice-free Greenland (MIS11NG). In this simulation, the entire GIS was removed and replaced with bare soil, and the topography of Greenland was corrected for glacial isostatic adjustment. The final sensitivity experiment included an increase in subsea ice surface heat flux from $2 \mathrm{~W} \mathrm{~m}^{-2}$ in our preindustrial control to $10 \mathrm{~W} \mathrm{~m}^{-2}$ (additional $+8 \mathrm{~W} \mathrm{~m}^{-2}$ ) to test the Beringian sensitivity to a mostly ice-free Arctic Ocean. The increased heat flux assumes an extreme $\sim 3$ sverdrup $(\mathrm{Sv})$ increase in the Bering Strait throughflow and a $4{ }^{\circ} \mathrm{C}$ temperature contrast between North Pacific and North Polar surface water (Melles et al., 2012, supplement). The additional heat flux convergence was used to crudely mimic the influence of a wider and deeper Bering Strait during times of higher sea levels. Using the predictive BIOME4 interactive vegetation model, direct comparisons of observed and modeled Arctic vegetation within the Lake E region can be made. Furthermore, simulations using prescribed distributions of biome flora can be used to quantify the local effect of changing vegetation cover around the region.

\subsection{MIS 31, $1072 \mathrm{ka}$}

MIS 31 ( 1062-1082 ka) (Lisiecki and Raymo, 2005) has only been identified in a few Arctic records prior to Lake E. The interglacial represents one of the last $41 \mathrm{kyr}$ glacial cycles and is best known for extreme warmth in circumAntarctic ocean waters induced by a deterioration of the polar front (Scherer et al., 2008) and the collapse of the marine-based West Antarctic Ice Sheet (WAIS) (DeConto et al., 2012; Pollard and DeConto, 2009) by the intrusion of warm surface waters onto Antarctic continental shelves. On Ellesmere Island, Fosheim Dome includes terrestrial deposits that date to $\sim 1.1 \mathrm{Ma}$, which contain fossil beetle assemblages dated to MIS 31, suggesting temperatures of 8 to $14{ }^{\circ} \mathrm{C}$ above modern values (Elias and Matthews Jr., 2002). It is speculated, as in the case of MIS 11c, that the Arctic may 
Table 1. Overview of interglacial simulations performed during this study. Orbital configurations are from Berger (1978) and greenhouse gas (GHG) concentrations from Hönisch et al. (2009), Loulergue et al. (2008), Lüthi et al. (2008) and Schilt et al. (2010). Modern GHG concentrations are taken from $\mathrm{AD} 1950$; obliquity and precession $(\Omega)$ are given in degrees.

\begin{tabular}{|c|c|c|c|c|c|c|c|}
\hline Date & Run description & $\begin{array}{r}\mathrm{CO}_{2} \\
(\mathrm{ppmv})\end{array}$ & $\begin{array}{r}\mathrm{CH}_{4} \\
(\mathrm{ppbv})\end{array}$ & $\begin{array}{r}\mathrm{N}_{2} \mathrm{O} \\
(\text { ppbv) }\end{array}$ & Eccentricity & $\begin{array}{r}\text { Obliquity } \\
\left({ }^{\circ}\right)\end{array}$ & $\begin{array}{r}\text { Precession } \\
\left(\Omega,^{\circ}\right)\end{array}$ \\
\hline AD 1850 & $\begin{array}{l}\text { preindustrial simulation with pre- } \\
\text { industrial GHG concentrations }\end{array}$ & 280 & 801 & 289 & 0.01671 & 23.438 & 101.37 \\
\hline $9 \mathrm{ka}$ & MIS 1 - with (modern) GIS & $\sim 260$ & $\sim 611$ & $\sim 263$ & 0.01920 & 24.229 & 310.32 \\
\hline $127 \mathrm{ka}$ & MIS 5e - with (modern) GIS & 287 & 724 & 262 & 0.03938 & 24.040 & 272.92 \\
\hline $409 \mathrm{ka}$ & MIS $11 \mathrm{c}$ - with (modern) GIS & 285 & 713 & 285 & 0.01932 & 23.781 & 265.34 \\
\hline $409 \mathrm{ka}$ & MIS $11 \mathrm{c}-$ no GIS & 285 & 713 & 285 & 0.01932 & 23.781 & 265.34 \\
\hline $409 \mathrm{ka}$ & $\begin{array}{l}\text { MIS } 11 \mathrm{c}-\text { no GIS }+10 \mathrm{~W} \mathrm{~m}^{-2} \\
\text { increase in heat flux under sea ice }\end{array}$ & 285 & 713 & 285 & 0.01932 & 23.781 & 265.34 \\
\hline $1072 \mathrm{ka}$ & MIS 31 - without GIS & 325 & 800 & 288 & 0.05597 & 23.898 & 289.79 \\
\hline
\end{tabular}

Table 2. List of GCM simulations with corresponding variables at the grid cell location of Lake E. Mean annual air temperature (MAAT), summer temperature (JJA), mean temperature of the warmest month (MTWM; July) and mean annual precipitation (PANN) are given below.

\begin{tabular}{|c|c|c|c|c|c|c|c|}
\hline Run & $\begin{array}{r}\text { Pre- } \\
\text { industrial }\end{array}$ & $\begin{array}{l}\text { MIS } 1- \\
\text { with GIS }\end{array}$ & $\begin{array}{l}\text { MIS } 5 \mathrm{e}- \\
\text { with GIS }\end{array}$ & $\begin{array}{r}\text { MIS 11c- } \\
\text { with GIS }\end{array}$ & $\begin{array}{r}\text { MIS } 11 \mathrm{c}- \\
\text { no GIS }\end{array}$ & $\begin{array}{r}\text { MIS 11c- } \\
\text { no GIS }+10 \mathrm{~W} \mathrm{~m}^{-2}\end{array}$ & $\begin{array}{r}\text { MIS } 31- \\
\text { without GIS }\end{array}$ \\
\hline \multicolumn{8}{|l|}{ Lake E } \\
\hline MAAT $\left({ }^{\circ} \mathrm{C}\right)$ & -12 & -12 & -12.4 & -11.5 & -12.5 & -10.5 & -10.4 \\
\hline Summer temp $\left(\mathrm{JJA} ;{ }^{\circ} \mathrm{C}\right)$ & 8 & 9.6 & 10.5 & 10 & 10.2 & 10.5 & 11.8 \\
\hline $\operatorname{MTWM}\left(\mathrm{July},{ }^{\circ} \mathrm{C}\right)$ & 10.3 & 12.4 & 14.5 & 12.2 & 12.5 & 13.2 & 13.8 \\
\hline PANN (mm yr $\left.{ }^{-1}\right)$ & 438 & 438 & 401 & 475 & 438 & 475 & 438 \\
\hline
\end{tabular}

have been too warm to support a GIS, which may have been substantially reduced in size or possibly nonexistent (Melles et al., 2012; Raymo and Mitrovica, 2012). Therefore, simulations of MIS 31 were run both with and without a GIS (see Tables 1 and 2).

\section{Results}

\subsection{Control simulation}

Preindustrial

Simulations of preindustrial $2 \mathrm{~m}$ mean annual air temperature (MAAT) and mean temperature of the warmest month (MTWM) (July) at Lake $\mathrm{E}$ are -12 and $10.3^{\circ} \mathrm{C}$ respectively. Preindustrial summer temperatures $\left(8^{\circ} \mathrm{C}\right)$ are $-2.2^{\circ} \mathrm{C}$ lower than modern temperatures. GHG radiative forcing from a combination of $\mathrm{CO}_{2}, \mathrm{CH}_{4}$ and $\mathrm{N}_{2} \mathrm{O}$ atmospheric mixing ratios implies a $1.8 \mathrm{~W} \mathrm{~m}^{-2}$ reduction compared to modern values, accounting for most of the cooling in the preindustrial simulation. Generally, mean annual precipitation (PANN) values in the cooler, preindustrial simulation are slightly lower than modern precipitation. At Lake E, preindustrial annual precipitation was $438 \mathrm{~mm}_{\text {year }}{ }^{-1}$. Winter (DJF) precipitation in the preindustrial simulation was $\sim 24 \mathrm{~mm} \mathrm{month}^{-1}$, while mean summer (JJA) precipitation was $43 \mathrm{~mm} \mathrm{month}^{-1}$.
Simulated preindustrial vegetation distributions are assumed to be in equilibrium (Fig. 2a). In the preindustrial simulation, shrub tundra dominates the Lake $\mathrm{E}$ region, with evergreen taiga and deciduous forests maintained in interior Siberia and Yukon. Simulated Siberian biome distributions are similar to modern-day vegetation described by Kolosova (1980) and Viereck and Little Jr. (1975). Shrub tundra in the preindustrial simulation can be attributed to cool and dry Arctic conditions in the preindustrial run.

\subsection{Paleoclimate simulations}

\subsubsection{MIS 1 (9 ka); Holocene Thermal Maximum}

July temperatures at Lake $\mathrm{E}$ in the MIS- 1 simulation $\left(12.4^{\circ} \mathrm{C}\right)$ are $\sim 2.1^{\circ} \mathrm{C}$ warmer than preindustrial $\left(10.3{ }^{\circ} \mathrm{C}\right)$ and summer (JJA) temperatures are $1.6^{\circ} \mathrm{C}$ warmer (Fig. 3a). Overall, the Siberian interior warms $>5^{\circ} \mathrm{C}$ in July compared to preindustrial temperatures. Simulated MTWM exceeds $>2{ }^{\circ} \mathrm{C}$ around Lake E.

Simulated MIS-1 PANN values at the lake $\left(\sim 438 \mathrm{~mm}\right.$ year $\left.^{-1}\right)$ are close to preindustrial values, although somewhat drier conditions dominate further inland, a result possibly attributable to increased distance from a moisture source. Simulated vegetation around Lake E is 

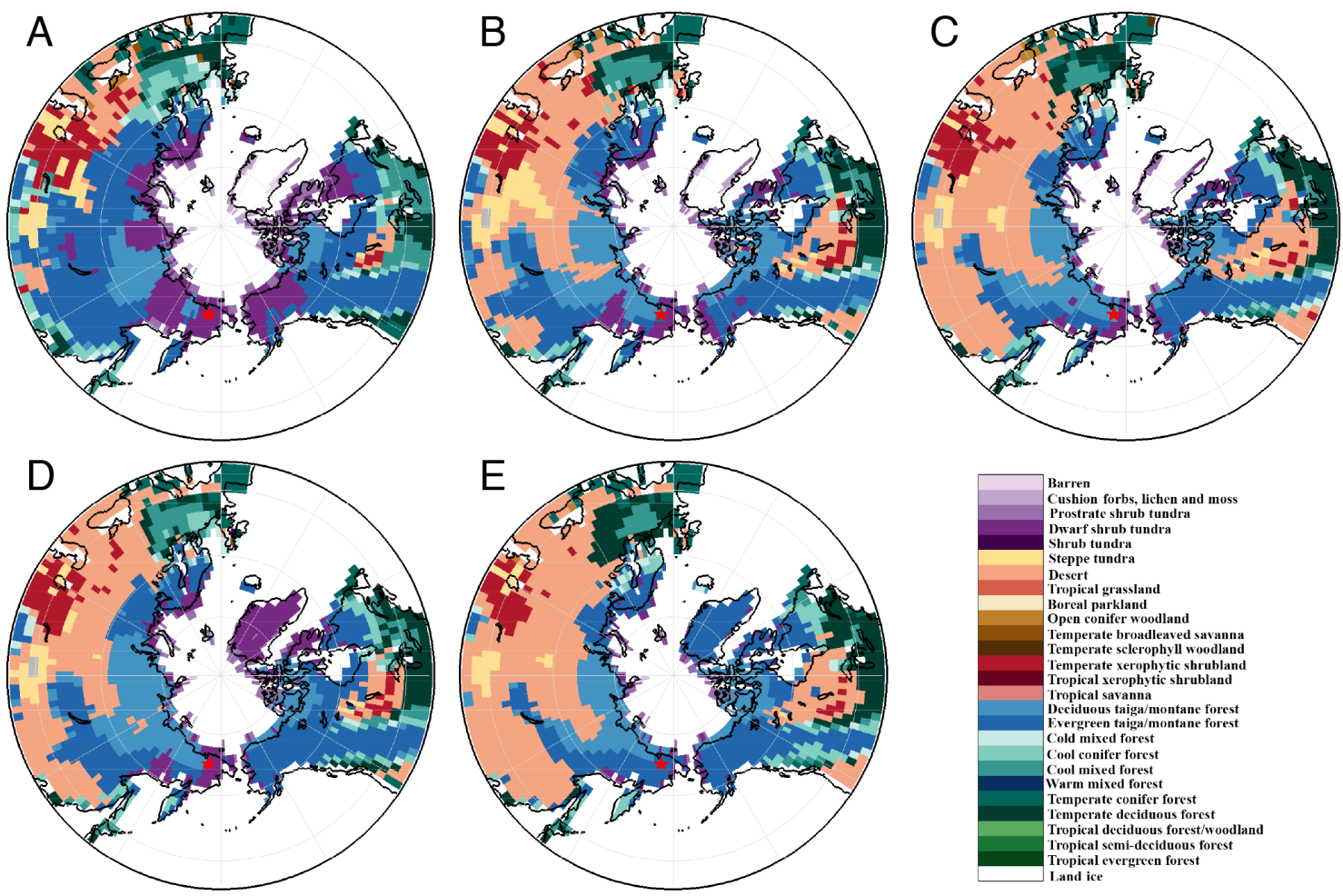

Figure 2. Distribution of interglacial vegetation simulated by the BIOME4 interactive vegetation model coupled to the GCM: (a) preindustrial vegetation corresponding to a modern orbit, (b) MIS 1 (9 ka), (c) MIS-5e vegetation, (d) MIS11NG vegetation and (e) MIS-31 (no GIS) vegetation. The location of Lake $\mathrm{E}$ is shown near the bottom of each figure with a red star. Note the poleward advancement of evergreen and needleleaf trees around the lake during each interglacial and the replacement of shrub tundra to taiga forest (vegetation data from Melles et al., 2012).

close to the transition between dominant shrub tundra to the east and deciduous forest to the west (Fig. 2b).

\subsubsection{MIS 5e (127 ka)}

Overall warming of the Beringian interior in the MIS-5e simulation is $>2{ }^{\circ} \mathrm{C}$ than preindustrial temperatures (Fig. 3b). Most of this warming can be attributed to the direct effects of the MIS-5e orbit (Groll et al., 2005; Langebroek and Nisancioglu, 2014), which produces an Arctic summer insolation anomaly of $>50 \mathrm{~W} \mathrm{~m}^{-2}$ at the top of the atmosphere compared to a preindustrial (modern) orbit (Fig. 4b). According to ice core records, carbon dioxide $\left(\mathrm{CO}_{2}\right)$ concentrations during this period were about $287 \mathrm{ppmv}$ (Hönisch et al., 2009), contributing $0.132 \mathrm{~W} \mathrm{~m}^{-2}$ more surface radiative forcing than in the preindustrial period, but the combination of $\mathrm{CO}_{2}, \mathrm{CH}_{4}$ and $\mathrm{N}_{2} \mathrm{O}$ contributes $0.0035 \mathrm{~W} \mathrm{~m}^{-2}$ less forcing than to preindustrial GHG mixing ratios.

Comparing MIS 5e with respect to the preindustrial control simulation at Lake $\mathrm{E}$ shows differences in summer (JJA) and MTWM temperatures of +2.5 and $+4.2^{\circ} \mathrm{C}$, respectively (Fig. 3b). Summer warming over the GIS is $+5^{\circ} \mathrm{C}$ compared to preindustrial warming; this is comparable to the LIG warming reported in a recent Greenland ice core study (Dahl-Jensen and NEEM community members, 2013). Mean annual precipitation at Lake E $\left(\sim 401 \mathrm{~mm} \mathrm{year}^{-1}\right)$ is $37 \mathrm{~mm}$ year $^{-1}$ less than preindustrial levels, and the difference is statistically significant at the $95 \%$ confidence level with a $p$ value of 0.029 . Overall, similar precipitation patterns are seen at Lake E as in MIS 5e and the preindustrial control scenario; this reflects both the overall wet bias in the GCM and the similar continental-ice-sheet boundary conditions in both simulations.

A less moist, but warm high-latitude environment produces deciduous taiga and evergreen taiga biome distributions around Lake E (Fig. 2c), with evergreen taiga being the most dominant in eastern Beringia and deciduous taiga being more dominant around the Lake $\mathrm{E}$ region and most of western Beringia.

\subsubsection{MIS 11c (409 ka)}

Due to an eccentricity minimum, MIS $11 \mathrm{c}$ is a longer interglacial than the other interglacials in this study (Howard, 1997). We assume an ice-free Greenland in our MIS-11c simulations, with the ice sheet removed and replaced with isostatically equilibrated (ice-free) land elevations. Additional 


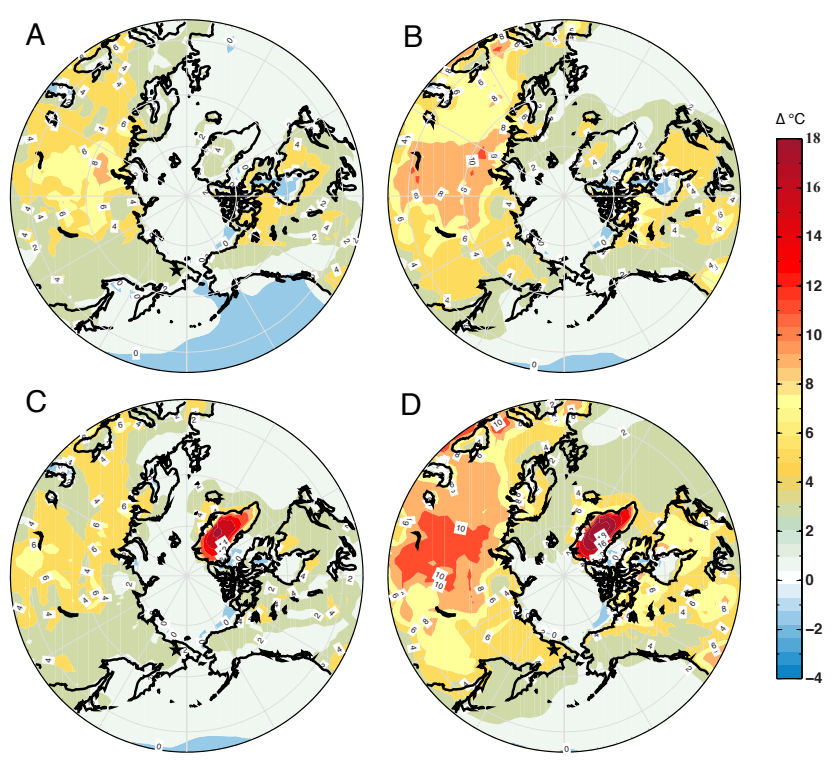

Figure 3. Simulated interglacial anomalies ( $2 \mathrm{~m}$ annual air temperature in ${ }^{\circ} \mathrm{C}$ ) compared to preindustrial temperatures: (a) MIS 1 (9 ka orbit and GHGs), (b) MIS 5e (127 ka orbit and GHGs), (c) MIS 11c (409 ka orbit and GHGs but no Greenland Ice Sheet) and (d) MIS 31 (1072 ka orbit and GHGs but no Greenland Ice Sheet). The location of Lake E (black star) is shown near the bottom of each panel. Areas of no shading (white) roughly correspond to no change that is statistically significant at the $95 \%$ confidence interval.

experiments including an imposed increase in subsea ice heat flux in the Arctic Ocean basin will also be discussed.

Model simulations show summer insolation anomalies (compared to the preindustrial period) during MIS 11c ranging from +45 to $55 \mathrm{~W} \mathrm{~m}^{-2}$ (Fig. 4c) and allowing temperatures over the Lake E region during July (month of maximum insolation) to increase $2.2{ }^{\circ} \mathrm{C}$ compared to the preindustrial period. Overall, mean annual summer temperatures (JJA) over the circum-Arctic and Lake $\mathrm{E}$ are 2 to $4{ }^{\circ} \mathrm{C}$ warmer than preindustrial temperatures, with the Siberian interior warming the most (Table 2).

In MIS-11c simulations performed with (MIS11GIS) and without a GIS (MIS11NG), the effect on temperature at Lake $\mathrm{E}$ is shown to be small $\left(\sim 0.3^{\circ} \mathrm{C}\right)$. Geopotential height anomalies at $500 \mathrm{hPa}(+4-10 \mathrm{~m})$ indicate upper-level warming east of Lake $\mathrm{E}$ and cooling west of Lake $\mathrm{E}$, but the net effect of ice sheet loss on surface air temperatures is mostly limited to Greenland itself and the proximal ocean, with little effect further away at Lake E, as shown in other modeling studies (Koenig et al., 2012; Otto-Bliesner et al., 2006).

The warm MIS-11c climate and possible reductions in Greenland and West Antarctic ice sheets are thought to have contributed to sea levels as much as $>11 \mathrm{~m}$ (Raymo and Mitrovica, 2012) higher than today. Arctic sea ice was also possibly reduced (Cronin et al., 2013; Polyak et al., 2010). In order to test the influence of high sea levels and a mostly ice-free Arctic Ocean on Lake E climate, heat flux conver- gence under sea ice was increased from 2 to $10 \mathrm{~W} \mathrm{~m}^{-2}$ in the slab ocean-dynamic sea ice model. The resulting reductions in sea ice extent and warmer $\left(\sim 0.2-1.0^{\circ} \mathrm{C}\right)$ (Fig. 5a) Arctic SSTs produced negligible warming around Lake E $\left(<0.7^{\circ} \mathrm{C}\right)$, suggesting that the Lake $\mathrm{E}$ region was relatively insensitive to Arctic Ocean conditions.

Precipitation amounts at Lake E during MIS11GIS are greater than preindustrial values $\left(438 \mathrm{~mm} \mathrm{year}^{-1}\right)$. Also, MIS11NG exhibits the same precipitation amounts as our preindustrial control run $\left(\sim 438 \mathrm{~mm} \mathrm{year}^{-1}\right)$ (Table 2$)$. Simulated precipitation conditions in the Arctic Ocean basin are fairly dry $\left(\sim 200 \mathrm{~mm} \mathrm{year}^{-1}\right)$, comparable to reanalysis data sets (Serreze and Hurst, 2000). By contrast, simulations of MIS11NG show precipitation amounts reduced by $-37 \mathrm{~mm}$ year $^{-1}$ compared to MIS11GIS. Runs with increased sub-ice oceanic heat flux reduced the drying seen in the MIS11NG simulation and produced values greater than the preindustrial control $\left(\sim 475 \mathrm{~mm}_{\text {year }}{ }^{-1}\right)$.

A warmer and wetter MIS 11c places Lake E on the border of evergreen taiga and shrub tundra biomes (Fig. 2d). Vegetation limits, such as tree lines, are slightly changed during our simulations with increased heat flux and a warmer, open Arctic Ocean. Evergreen forests around the Lake E region extend poleward to the coast and slightly eastward.

\subsubsection{MIS 31 (1072 ka)}

A warm orbit with high obliquity, high eccentricity and precession aligning perihelion with boreal summer allows insolation anomalies to be $>50 \mathrm{~W} \mathrm{~m}^{-2}$ at the surface and +60 $80 \mathrm{~W} \mathrm{~m}^{-2}$ (Fig. 4d) at the top of the atmosphere at the latitude of Lake E. Average summer (JJA) temperatures around the lake are about $+3.8^{\circ} \mathrm{C}$ warmer than in the preindustrial period (Fig. 3d; Table 2). While MIS 31 is beyond the temporal range of ice core greenhouse gas records, proxy geochemical records imply that MIS 31 has the highest $p \mathrm{CO}_{2}$ ( $325 \mathrm{ppmv}$ ) of the mid-Pleistocene (Hönisch et al., 2009), contributing $\sim+0.80 \mathrm{~W} \mathrm{~m}^{-2}$ compared to preindustrial values. As a result, modeled July temperatures at Lake E are $>5^{\circ} \mathrm{C}$ warmer than preindustrial temperatures.

Simulated precipitation at Lake E during MIS 31 is $\sim 438 \mathrm{~mm}$ year $^{-1}$ (Table 2), similar to that in MIS-11c simulations. Vegetation distribution is similar to the other interglacials described here (Fig. 2e). The Lake E region is dominated by evergreen taiga.

\section{Discussion}

The warm periods of Marine Isotope Stages 1, 5e, 11c and 31 show similar changes around Lake E. Temperature reconstructions during the Holocene Thermal Maximum (9 ka) indicate a $+1.6( \pm 0.8)^{\circ} \mathrm{C}$ warming in the western Arctic (Kaufman and Brigham-Grette, 1993), with an overall warming of $1.7( \pm 0.8)^{\circ} \mathrm{C}$ in the circum-Arctic (Miller et al., 2010a) compared to modern temperatures. Though our 
A

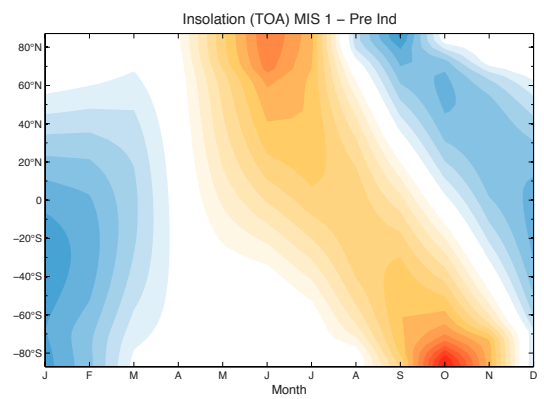

C

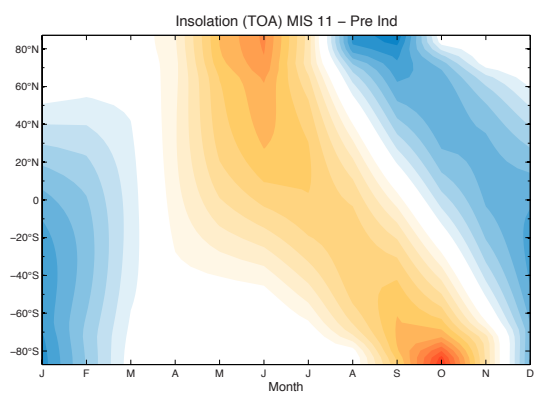

B

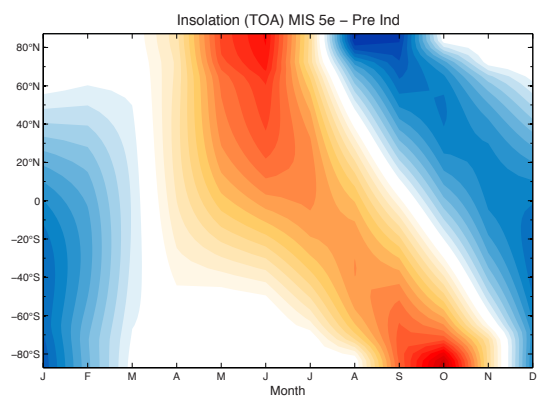

D

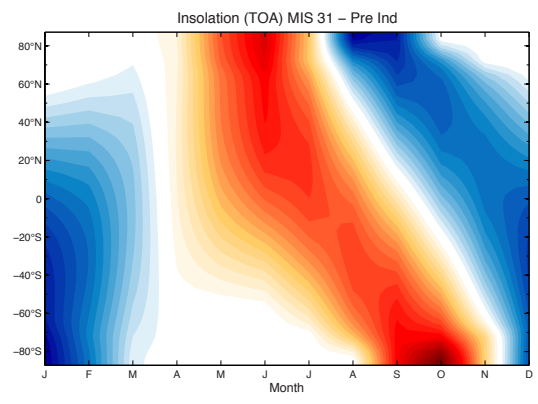

$\Delta \mathrm{W} / \mathrm{m}^{2}$

$-80-70-60-50-40-30-20-10 \quad 0 \quad 102030405060708090100110120$

Figure 4. Monthly insolation anomalies at the top of the atmosphere for the interglacial intervals modeled here (W m ${ }^{-2}$ ). (a) MIS-1 anomalies with respect to preindustrial (modern) orbit, (b) MIS-5e anomalies with respect to preindustrial orbit, (c) MIS-11c anomalies with respect to preindustrial orbit and (d) MIS-31 anomalies with respect to preindustrial orbit.

model does not fully account for all the warming during this period, it does produce the warming in the western Arctic as documented by Kaufman and Brigham-Grette (1993). With the decrease in Arctic moisture and low $\mathrm{CO}_{2}$, deciduous and evergreen forests dominate the Arctic in the model, matching the dominant vegetation such as Alnus, Betula (nut-bearing trees and fruits), Poaceae (grasses) and some birch and alder seen in the Lake E record (Melles et al., 2012).

Marine Isotope Stage 5e produced the greatest summer warming among the four interglacials simulated here. Comparisons with a preindustrial control run show that differences in MTWM at Lake E during MIS 1 and 5e $(+2.1$ and $+4.2^{\circ} \mathrm{C}$ ) are similar to the changes seen in MIS11NG and MIS $31\left(+2.2\right.$ and $+3.5^{\circ} \mathrm{C}$ ) (Table 2). Similar warming has been seen in other modeling studies, showing that a high obliquity and high eccentricity with precession aligning perihelion with boreal summer will yield the warmest boreal summer temperatures (Koenig et al., 2011; Lunt et al., 2013; Otto-Bliesner et al., 2006; Yin and Berger, 2011). Strong insolation forcing at these latitudes causes July maximum temperatures to exceed preindustrial temperatures by $>2{ }^{\circ} \mathrm{C}$. The $2-4^{\circ} \mathrm{C}$ simulated MIS-5e warming in Siberia and Lake $\mathrm{E}$ has also been seen in proxy data compilations (CAPE, 2006; Lozhkin and Anderson, 1995; Lozhkin et al., 2006) and in simulations using a GCM without vegetation feedbacks (Otto-Bliesner et al., 2006). Most of the warming has been linked to the summer insolation anomaly associated with the MIS-5e orbit (Otto-Bliesner et al., 2006). The exceptional summer warmth of MIS 5e compared to other interglacials was previously thought to have caused a substantial reduction in the GIS; however, more recent work suggests the GIS contributed only $\sim 1.4$ to $4.3 \mathrm{~m}$ of equivalent eustatic sea level rise during the LIG (Colville et al., 2011; Quiquet et al., 2013; Robinson et al., 2011; Stocker et al., 2013; Stone et al., 2013) and remained mostly intact (Dahl-Jensen and NEEM community members, 2013). This suggests that our simulations of MIS 5e with a modern GIS are a good approximation for this period. Colder and fresher sea surface conditions in the North Atlantic, Labrador and Norwegian seas have been found in marine sediment records, possibly indicating freshwater input (perhaps from parts of Greenland) which may have led to early LIG warming attributed to stronger ocean overturning (Govin et al., 2012). In the model, Arctic warming during MIS 5e allows almost a full replacement of shrub tundra with deciduous forest in and around the Lake E region. Pollen analysis during this period shows tree species of birch, alder, pine and spruce (Melles et al., 2012). However, multiproxy studies of MIS 5e show a change in MTWM of only $+2{ }^{\circ} \mathrm{C}$ compared to modern temperatures (Melles et al., 2012) (Table 2). It can be concluded that the warm boreal 
summer orbit at MIS 5e can account for much of the warmth in Beringia and the circum-Arctic, but the particularly muted response in the Lake E proxy record to summer insolation forcing cannot be fully explained.

Simulations of MIS 11c show another very warm interglacial at Lake E, with MTWM maxima almost $+2.2{ }^{\circ} \mathrm{C}$ warmer than preindustrial temperatures (Table 2). Similarly to MIS 5e and 1, peak warmth coincides with perihelion during boreal summer; however, low eccentricity and obliquity attenuates the effects of precession compared to 5e and 1, making summer insolation less intense. A combination of eccentricity, obliquity and precession elevates summer insolation for $\sim 45000$ years, a much longer (but less intense) interval of elevated summer insolation than during the other interglacials studied here. The overall warmth of MIS 11 is, in part, an outcome of reduced snow and ice cover.

Another possible mechanism contributing to Lake E warmth at MIS 11 might be related to elevated sea levels at this time (Raymo and Mitrovica, 2012), possibly contributing to increased Bering Strait throughflow. Today, the Bering Strait is limited to $\sim 50 \mathrm{~m}$ in depth, with a net northward transport of $\sim 0.8 \mathrm{~Sv}$ (Woodgate et al., 2010). Oceanic heat transport into the Arctic Basin might have been elevated during high sea levels, providing a source of warm water intrusion into the Arctic Ocean basin from the North Pacific. As a simple test of the potential for a warmer Arctic Ocean with less sea ice to affect temperatures over terrestrial Beringia, heat flux convergence under sea ice in the Arctic Ocean was increased from 2 to $10 \mathrm{~W} \mathrm{~m}^{-2}$. The summer sea ice fraction was reduced by $25-50 \%$, and summer ocean temperatures warmed by $0.2-1.0^{\circ} \mathrm{C}$ (Fig. 5a, b). The simulated warming of the Arctic Ocean warmed the Lake E region, but only slightly $\left(+0.7^{\circ} \mathrm{C}\right)$, and it does not account for the exceptional warmth observed during MIS 11c compared to MIS 5e.

The influence of MIS-11c temperatures on terrestrial biome distributions is supported in model simulations by a poleward advance of evergreen needleleaf forest around the lake, which is in good agreement with palynological analysis (Melles et al., 2012) showing forest tundra and northern larch taiga dominated by spruce, pine, birch, alder and larch (Melles et al., 2012). Surface warming as a result of albedo feedbacks associated with needleleaf forests during snowcovered months accounts for some of the warming during this period; however, increased evergreen, terrestrial forest and enhanced evapotranspiration provides a slight net cooling during the summers.

A deglaciated Greenland has been shown to have regional effects on SSTs and sea ice conditions; however, the warming of the circum-Arctic has been shown to be minimal (Koenig et al., 2012; Otto-Bliesner et al., 2006). This is also demonstrated in our simulations, whereby the loss of the GIS warms summer annual temperatures around Lake $\mathrm{E}$ by only $0.3^{\circ} \mathrm{C}$ (Table 2). An analysis of $500 \mathrm{hPa}$ geopotential height anomalies shows ridging (positive height anomalies of $>10 \mathrm{~m}$ ) to the east and troughing (negative height anomalies) to the west of Lake E, indicating a slight change in the large-scale planetary wave patterns over Beringia. Over Lake E, positive height anomalies are also present, indicating slightly warmer conditions and a slight eastward shift of an atmospheric ridge that may have been set up further west of Lake E. The ridging in these simulations may also be related to a decrease in precipitation at Lake $\mathrm{E}$ when the GIS is removed in GCM. Extended high pressure over Beringia associated with ridging would create somewhat drier conditions for the region. If the exceptional warmth of MIS $11 \mathrm{c}$ is indeed related to the melting of the GIS, freshwater input may have been a mechanism that strengthened North Atlantic overturning and created the warmth missing in our simulations (Govin et al., 2012). Furthermore, it is not clear why the GIS would have survived MIS-5e warmth but not MIS 11c. In sum, the exceptional Arctic warmth of MIS 11c remains difficult to explain and is not a straightforward result of greenhouse gases, orbital forcing, vegetation feedbacks or Arctic Ocean warming.

Elevated GHG concentrations and a very warm summer orbit can explain much of the warmth during MIS 31, assuming atmospheric $\mathrm{CO}_{2}$ was higher than MIS 5e and MIS 11 (Hönisch et al., 2009). In the model, the combination of elevated greenhouse gases and strong summer insolation forcing at $1072 \mathrm{ka}$ allows dense needleleaf and deciduous forests to grow around the lake. Simulated summer temperatures are about $12^{\circ} \mathrm{C}$ (Table 2 ), $+2{ }^{\circ} \mathrm{C}$ warmer than modern summer temperatures around Lake E. Biome reconstructions derived from pollen analysis of the Lake E core (Melles et al., 2012) show a maximum of trees and shrubs during the peak Northern Hemisphere insolation of MIS 31 at $1072 \mathrm{ka}$. Our model simulations show similar results around Lake E, with increased boreal forest and less tundra and small dwarf shrubs. The snow-albedo effect combined with low-albedo forest cover allows temperatures to increase in the Arctic during MIS 31. Peak precipitation rates derived from proxy analysis indicate about $600 \mathrm{~mm}_{\text {year }}{ }^{-1}$, i.e., about $162 \mathrm{~mm}_{\text {year }}{ }^{-1}$ more precipitation than in our preindustrial model simulation (Melles et al., 2012). GCM results for MIS 31 indicate annual precipitation of $\sim 490 \mathrm{~mm}_{\text {year }}{ }^{-1}$ (Table 2), the most annual precipitation among the four interglacials simulated here. While the GCM does not fully capture the enhanced precipitation indicated in the proxy record, a relative increase in precipitation is evident. Extraordinary warmth during MIS 31 correlates well with a diminished WAIS (Pollard and DeConto, 2009), implying strong interhemispheric coupling that has been related to possible reductions in Antarctic Bottom Water (AABW) formation during times of ice-shelf retreat and increased freshwater input into the Southern Ocean (Foldvik, 2004). WAIS collapse could also be linked with the Beringian and Lake E warmth during MIS 11c and MIS $5 e$, but definitive evidence of WAIS retreat during these later Pleistocene interglacials is currently lacking (McKay et al., 2012). 

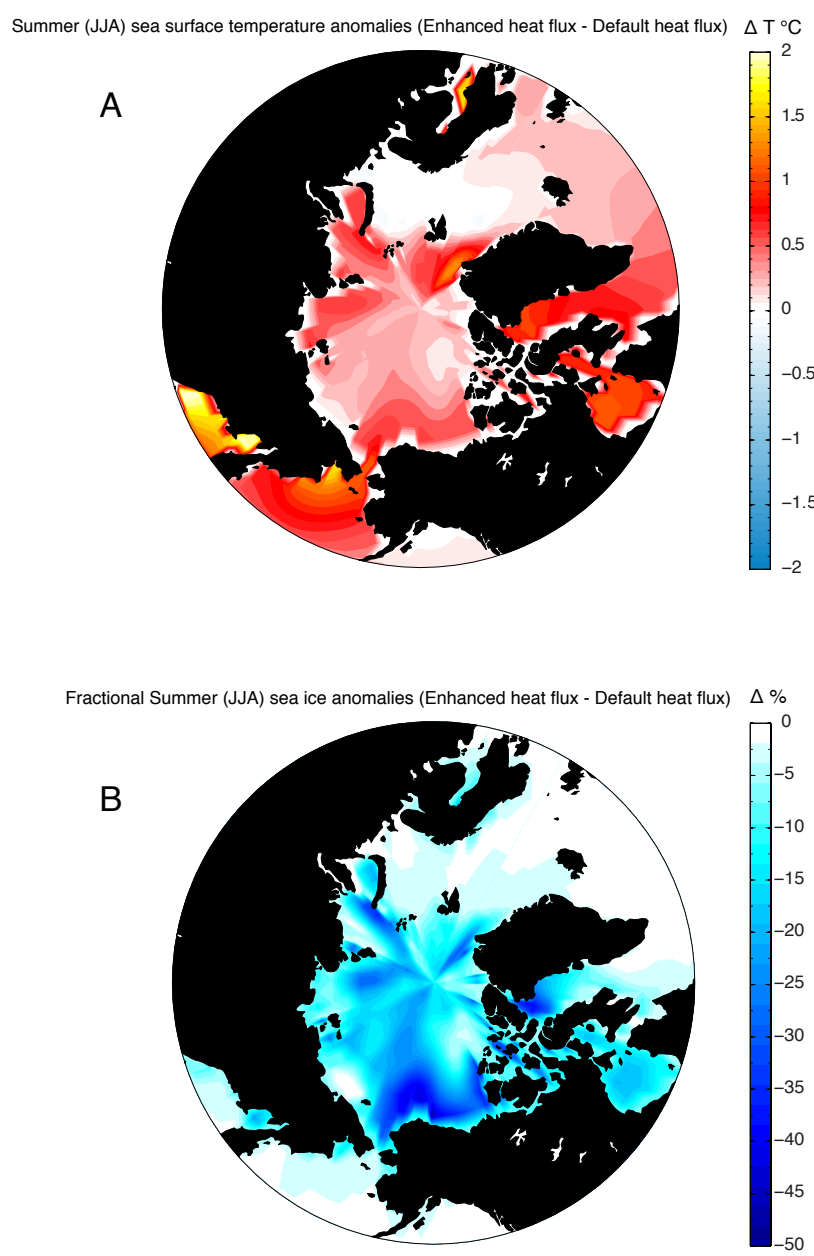

Figure 5. Model simulated (MIS11NG) summer sea surface temperature and sea ice anomalies caused by enhanced oceanic heat flux $\left(+8 \mathrm{~W} \mathrm{~m}^{-2}\right)$ at $409 \mathrm{ka}$ : (a) summer (JJA) sea surface temperature change with respect to default heat flux simulation $\left(T{ }^{\circ} \mathrm{C}\right)$ and (b) summer (JJA) sea ice fraction anomalies (\%) with respect to default heat flux simulation. With $+8 \mathrm{~W} \mathrm{~m}^{-2}$ of subsea ice heat flux convergence, Arctic Ocean SSTs rise $>0.5^{\circ} \mathrm{C}$ and sea ice fraction decreases $25-50 \%$ in most areas.

\section{Conclusions}

Lake E provides a high-resolution terrestrial proxy record of climate variability in the Arctic. A linked climate modeling study described here shows that Arctic summers were significantly warmer during several Pleistocene interglacials: by as much as $+2{ }^{\circ} \mathrm{C}$ during MIS 1 and $11 \mathrm{c}$ and by as much as $+4{ }^{\circ} \mathrm{C}$ during MIS 5e and 31 compared to preindustrial values. It can be inferred that most of the warming in the interglacial simulations can be attributed to a combination of elevated GHGs and astronomical forcing, although astronomical forcing (at times producing high-intensity summer insolation $>50 \mathrm{~W} \mathrm{~m}^{-2}$ higher than today) was the dominant warming mechanism. Greenhouse gas levels during MIS 31 remain poorly known, and the extreme warmth of this particular in- terglacial could have been substantially augmented by GHG forcing. MIS 1 had relatively low $\mathrm{CO}_{2}$ around the time of peak Holocene warmth, producing $0.44 \mathrm{~W} \mathrm{~m}^{-2}$ less radiative forcing than in the preindustrial period (Melles et al., 2012), but the combination of orbital forcing and perhaps other factors, such as changes in AABW production and reduced Arctic sea ice, may have contributed to exceptional Arctic warmth at this time. Thorough testing of these ideas will require additional simulations with coupled atmosphere-ocean models, changes in circum-Arctic ice sheets, eustatic sea levels, continentality, changes in sea ice distributions and the addition of meltwater inputs into Northern and Southern Hemisphere oceans.

Extreme interglacial warmth shifted Lake E vegetation from mostly tundra with small shrubs, as we see in the Arctic today, to thick, lush evergreen and boreal forest. Due to the extreme warmth, wetter conditions prevailed during the super-interglacials, allowing forest biomes to thrive and increase their maximum extent poleward. While simulated warming at Lake $\mathrm{E}$ is broadly similar during each interglacial, the vegetation response in each simulation is unique, reflecting differences in seasonal temperatures and hydroclimate. The simulated absence of a Greenland Ice Sheet allowed summer temperatures to increase to almost $16^{\circ} \mathrm{C}$ warmer than in the present over Greenland, but with a limited impact on temperatures around Lake $\mathrm{E}$. The observed response of Beringia's climate and terrestrial vegetation to super-interglacial forcing is still not fully understood and creates a challenge for climate modeling and for quantifying the strength of Arctic amplification. Among the interglacials studied here, MIS $11 \mathrm{c}$ is the warmest interglacial in the Lake E record, yet MIS 5e is the warmest simulated by the model. The model produces overall drier conditions in the earlier interglacials (11c and 31) than suggested by pollen analysis. If the proxy interpretations are correct, this suggests that the model is not taking into account some important regional processes. The timing of significant warming in the circum-Arctic can be linked to major deglaciation events in Antarctica, demonstrating possible interhemispheric linkages between the Arctic and Antarctic climate on glacial-interglacial timescales, which have yet to be explained.

Edited by: V. Rath

\section{References}

Alder, J. R., Hostetler, S. W., Pollard, D., and Schmittner, A.: Evaluation of a present-day climate simulation with a new coupled atmosphere-ocean model GENMOM, Geosci. Model Dev., 4, 69-83, doi:10.5194/gmd-4-69-2011, 2011.

Bakker, P., Stone, E. J., Charbit, S., Gröger, M., Krebs-Kanzow, U., Ritz, S. P., Varma, V., Khon, V., Lunt, D. J., Mikolajewicz, U., Prange, M., Renssen, H., Schneider, B., and Schulz, M.: Last 
interglacial temperature evolution - a model inter-comparison, Clim. Past, 9, 605-619, doi:10.5194/cp-9-605-2013, 2013.

Berger, A.: Long-Term Variations of Daily Insolation and Quaternary Climatic Changes, J. Atmos. Sci., 35, 2362-2367, doi:10.1175/1520-0469(1978)035<2362:LTVODI>2.0.CO;2, 1978.

Brigham-Grette, J., Melles, M., Minyuk, P., Andreev, A., Tarasov, P., DeConto, R., Koenig, S., Nowaczyk, N., Wennrich, V., Rosen, P., Haltia, E., Cook, T., Gebhardt, C., Meyer-Jacob, C., Snyder, J., and Herzschuh, U.: Pliocene Warmth, Polar Amplification, and Stepped Pleistocene Cooling Recorded in NE Arctic Russia, Science, 340, 1421-1427, doi:10.1126/science.1233137, 2013.

Colville, E. J., Carlson, A. E., Beard, B. L., Hatfield, R. G., Stoner, J. S., Reyes, A. V., and Ullman, D. J.: Sr-Nd-Pb Isotope Evidence for Ice-Sheet Presence on Southern Greenland During the Last Interglacial, Science, 333, 620-623, doi:10.1126/science.1204673, 2011.

Cronin, T. M., Polyak, L., Reed, D., Kandiano, E. S., Marzen, R. E. and Council, E. A.: A 600-ka Arctic sea-ice record from Mendeleev Ridge based on ostracodes, Sea Ice Paleoclimate Syst. Chall. Reconstr. Sea Ice Proxies, 79(0), 157-167, doi:10.1016/j.quascirev.2012.12.010, 2013.

Dahl-Jensen, D. and NEEM community members: Eemian interglacial reconstructed from a Greenland folded ice core, Nature, 493, 489-494, doi:10.1038/nature11789, 2013.

DeConto, R. M., Galeotti, S., Pagani, M., Tracy, D., Schaefer, K., Zhang, T., Pollard, D., and Beerling, D. J.: Past extreme warming events linked to massive carbon release from thawing permafrost, Nature, 484, 87-91, doi:10.1038/nature10929, 2012.

De Vernal, A. and Hillaire-Marcel, C.: Natural Variability of Greenland Climate, Vegetation, and Ice Volume During the Past Million Years, Science, 320, 1622-1625, doi:10.1126/science.1153929, 2008.

Elias, S. A. and Matthews Jr., J. V.: Arctic North American seasonal temperatures from the latest Miocene to the Early Pleistocene, based on mutual climatic range analysis of fossil beetle assemblages, Can. J. Earth Sci., 39, 911-920, doi:10.1139/e01096, 2002

Foldvik, A.: Ice shelf water overflow and bottom water formation in the southern Weddell Sea, J. Geophys. Res., 109, 1-15, doi:10.1029/2003JC002008, 2004.

Govin, A., Braconnot, P., Capron, E., Cortijo, E., Duplessy, J.-C., Jansen, E., Labeyrie, L., Landais, A., Marti, O., Michel, E., Mosquet, E., Risebrobakken, B., Swingedouw, D., and Waelbroeck, C.: Persistent influence of ice sheet melting on high northern latitude climate during the early Last Interglacial, Clim. Past, 8, 483-507, doi:10.5194/cp-8-483-2012, 2012.

Groll, N., Widmann, M., Jones, J. M., Kaspar, F., and Lorenz, S. J.: Simulated relationships between regional temperatures and large-scale circulation: $125 \mathrm{kyr} \mathrm{BP}$ (Eemian) and the preindustrial period, J. Clim., 18, 4032-4045, 2005.

Hönisch, B., Hemming, N. G., Archer, D., Siddall, M., and McManus, J. F.: Atmospheric Carbon Dioxide Concentration Across the Mid-Pleistocene Transition, Science, 324, 15511554, doi:10.1126/science.1171477, 2009.

Howard, W. R.: Palaeoclimatology: A warm future in the past, Nature, 388, 418-419, 1997.
Kaplan, J. O.: Climate change and Arctic ecosystems: 2. Modeling, paleodata-model comparisons, and future projections, J. Geophys. Res., 108, 1-17, doi:10.1029/2002JD002559, 2003.

Kaufman, D. S. and Brigham-Grette, J.: Aminostratigraphic correlations and paleotemperature implications, Pliocene-Pleistocene high-sea-level deposits, northwestern Alaska, Quaternary Sci Rev., 12, 21-33, doi:10.1016/0277-3791(93)90046-O, 1993.

Kitoh, A. and Murakami, S.: Tropical Pacific climate at the midHolocene and the Last Glacial Maximum simulated by a coupled ocean-atmosphere general circulation model, Paleoceanography, 17, 19-1-19-13, doi:10.1029/2001PA000724, 2002.

Koenig, S. J., DeConto, R. M., and Pollard, D.: Late Pliocene to Pleistocene sensitivity of the Greenland Ice Sheet in response to external forcing and internal feedbacks, Clim. Dyn., 37, 12471268, doi:10.1007/s00382-011-1050-0, 2011.

Koenig, S. J., DeConto, R. M., and Pollard, D.: Pliocene Model Intercomparison Project Experiment 1: implementation strategy and mid-Pliocene global climatology using GENESIS v3.0 GCM, Geosci. Model Dev., 5, 73-85, doi:10.5194/gmd-5-732012, 2012.

Kolosova, L. (Ed.): The geographic atlas, 4th edn., 4th ed., Central Office of Geodesy and Cartography of the Soviet Ministry of the USSR, Moscow, Russia, 238 pp., 1980.

Langebroek, P. M. and Nisancioglu, K. H.: Simulating last interglacial climate with NorESM: role of insolation and greenhouse gases in the timing of peak warmth, Clim. Past, 10, 1305-1318, doi:10.5194/cp-10-1305-2014, 2014.

Lisiecki, L. E. and Raymo, M. E.: A Pliocene-Pleistocene stack of 57 globally distributed benthic $\delta 18 \mathrm{O}$ records, Paleoceanography, 20, PA1003, doi:10.1029/2004PA001071, 2005.

Loulergue, L., Schilt, A., Spahni, R., Masson-Delmotte, V., Blunier, T., Lemieux, B., Barnola, J.-M., Raynaud, D., Stocker, T. F., and Chappellaz, J.: Orbital and millennial-scale features of atmospheric $\mathrm{CH} 4$ over the past 800,000 years, Nature, 453, 383 386, doi:10.1038/nature06950, 2008.

Lozhkin, A. V. and Anderson, P. M.: The Last Interglaciation in Northeast Siberia, Quaternary Res., 43, 147-158, 1995.

Lozhkin, A. V., Anderson, P. M., Matrosova, T. V., and Minyuk, P. S.: The pollen record from El'gygytgyn Lake: implications for vegetation and climate histories of northern Chukotka since the late middle Pleistocene, J. Paleolimnol., 37, 135-153, doi:10.1007/s10933-006-9018-5, 2006.

Lunt, D. J., Abe-Ouchi, A., Bakker, P., Berger, A., Braconnot, P., Charbit, S., Fischer, N., Herold, N., Jungclaus, J. H., Khon, V. C., Krebs-Kanzow, U., Langebroek, P. M., Lohmann, G., Nisancioglu, K. H., Otto-Bliesner, B. L., Park, W., Pfeiffer, M., Phipps, S. J., Prange, M., Rachmayani, R., Renssen, H., Rosenbloom, N., Schneider, B., Stone, E. J., Takahashi, K., Wei, W., Yin, Q., and Zhang, Z. S.: A multi-model assessment of last interglacial temperatures, Clim. Past, 9, 699-717, doi:10.5194/cp-9-699-2013, 2013.

Lüthi, D., Le Floch, M., Bereiter, B., Blunier, T., Barnola, J.-M., Siegenthaler, U., Raynaud, D., Jouzel, J., Fischer, H., Kawamura, K., and Stocker, T. F.: High-resolution carbon dioxide concentration record 650,000-800,000 years before present, Nature, 453, 379-382, doi:10.1038/nature06949, 2008.

McKay, R., Naish, T., Powell, R., Barrett, P., Scherer, R., Talarico, F., Kyle, P., Monien, D., Kuhn, G., Jackolski, C., and Williams, T.: Pleistocene variability of Antarctic Ice Sheet ex- 
tent in the Ross Embayment, Quaternary Sci. Rev., 34, 93-112, doi:10.1016/j.quascirev.2011.12.012, 2012.

Melles, M., Brigham-Grette, J., Minyuk, P. S., Nowaczyk, N. R., Wennrich, V., DeConto, R. M., Anderson, P. M., Andreev, A. A., Coletti, A., Cook, T. L., Haltia-Hovi, E., Kukkonen, M., Lozhkin, A. V., Rosen, P., Tarasov, P., Vogel, H., and Wagner, B.: 2.8 Million Years of Arctic Climate Change from Lake El'gygytgyn, NE Russia, Science, 337, 315-320, doi:10.1126/science.1222135, 2012.

Miller, G. H., Alley, R. B., Brigham-Grette, J., Fitzpatrick, J. J., Polyak, L., Serreze, M. C., and White, J. W. C.: Arctic amplification: can the past constrain the future?, Quaternary Sci. Rev., 29, 1779-1790, doi:10.1016/j.quascirev.2010.02.008, 2010a.

Miller, G. H., Brigham-Grette, J., Alley, R. B., Anderson, L., Bauch, H. A., Douglas, M. S. V., Edwards, M. E., Elias, S. A., Finney, B. P., Fitzpatrick, J. J., Funder, S. V., Herbert, T. D., Hinzman, L. D., Kaufman, D. S., MacDonald, G. M., Polyak, L., Robock, A., Serreze, M. C., Smol, J. P., Spielhagen, R., White, J. W. C., Wolfe, A. P., and Wolff, E. W.: Temperature and precipitation history of the Arctic, Spec. Theme Arct. Palaeoclim. Synth. 1674-1790, 29, 1679-1715, doi:10.1016/j.quascirev.2010.03.001, $2010 \mathrm{~b}$.

Otto-Bliesner, B. L., Marshall, S. J., Overpeck, J. T., Miller, G. H., Hu, A., and CAPE Last Interglacial Project Members: Simulating Arctic Climate Warmth and Icefield Retreat in the Last Interglaciation, Science, 311, 1751-1753, doi:10.1126/science.1120808, 2006.

Pollard, D. and DeConto, R. M.: Modelling West Antarctic ice sheet growth and collapse through the past five million years, Nature, 458, 329-332, doi:10.1038/nature07809, 2009.

Polyak, L., Alley, R. B., Andrews, J. T., Brigham-Grette, J., Cronin, T. M., Darby, D. A., Dyke, A. S., Fitzpatrick, J. J., Funder, S., Holland, M., Jennings, A. E., Miller, G. H., O'Regan, M., Savelle, J., Serreze, M., St. John, K., White, J. W. C., and Wolff, E.: History of sea ice in the Arctic, Spec. Theme Arct. Palaeoclim. Synth. 1674-1790, 29, 1757-1778, doi:10.1016/j.quascirev.2010.02.010, 2010.

Prokopenko, A. A., Bezrukova, E. V., Khursevich, G. K., Solotchina, E. P., Kuzmin, M. I., and Tarasov, P. E.: Climate in continental interior Asia during the longest interglacial of the past 500000 years: the new MIS 11 records from Lake Baikal, SE Siberia, Clim. Past, 6, 31-48, doi:10.5194/cp-6-312010, 2010.

Quiquet, A., Ritz, C., Punge, H. J., and Salas y Mélia, D.: Greenland ice sheet contribution to sea level rise during the last interglacial period: a modelling study driven and constrained by ice core data, Clim. Past, 9, 353-366, doi:10.5194/cp-9-353-2013, 2013.

Raymo, M. E. and Mitrovica, J. X.: Collapse of polar ice sheets during the stage 11 interglacial, Nature, 483, 453-456, doi:10.1038/nature10891, 2012.

Robinson, A., Calov, R., and Ganopolski, A.: Greenland ice sheet model parameters constrained using simulations of the Eemian Interglacial, Clim. Past, 7, 381-396, doi:10.5194/cp-7-381-2011, 2011.
Scherer, R. P., Bohaty, S. M., Dunbar, R. B., Esper, O., Flores, J.-A., Gersonde, R., Harwood, D. M., Roberts, A. P., and Taviani, M.: Antarctic records of precession-paced insolation-driven warming during early Pleistocene Marine Isotope Stage 31, Geophys. Res. Lett., 35, 1-15, doi:10.1029/2007GL032254, 2008.

Schilt, A., Baumgartner, M., Blunier, T., Schwander, J., Spahni, R., Fischer, H., and Stocker, T. F.: Glacial-interglacial and millennial-scale variations in the atmospheric nitrous oxide concentration during the last 800,000 years, Quaternary Sci. Rev., 29, 182-192, doi:10.1016/j.quascirev.2009.03.011, 2010.

Serreze, M. C. and Hurst, C. M.: Representation of Mean Arctic Precipitation from NCEP-NCAR and ERA Reanalyses, J. Clim., 13, 182-201, doi:10.1175/15200442(2000)013<0182:ROMAPF>2.0.CO;2, 2000.

Stocker, T. F., Qin, D., Plattner, G.-K., Tignor, M., Allen, S. K., Boschung, J., Nauels, A., Xia, Y., Bex, V., and Midgley, P. (Eds.): IPCC,2013: Climate Change 2013: The Physical Science Basis. Contribution of Working Group I to the Fifth Assessment Report of the Intergovernmental Panel on Climate Change, Camb. Univ. Press Camb. UK N. Y. NY USA, 1535 pp., doi:10.1017/CBO9781107415324, 2013.

Stone, E. J., Lunt, D. J., Annan, J. D., and Hargreaves, J. C.: Quantification of the Greenland ice sheet contribution to Last Interglacial sea level rise, Clim. Past, 9, 621-639, doi:10.5194/cp-9621-2013, 2013.

Tarasov, P. E., Nakagawa, T., Demske, D., Österle, H., Igarashi, Y., Kitagawa, J., Mokhova, L., Bazarova, V., Okuda, M., Gotanda, K., Miyoshi, N., Fujiki, T., Takemura, K., Yonenobu, H., and Fleck, A.: Progress in the reconstruction of Quaternary climate dynamics in the Northwest Pacific: A new modern analogue reference dataset and its application to the 430-kyr pollen record from Lake Biwa, Earth-Sci. Rev., 108, 64-79, doi:10.1016/j.earscirev.2011.06.002, 2011.

Thompson, S. L. and Pollard, D.: Greenland and Antarctic mass balances for present and doubled atmospheric $\mathrm{CO} 2$ from the GENESIS version-2 global climate model, J. Clim., 10, 871-900, 1997.

Viereck, L. A. and Little Jr., E. L.: Atlas of United States Trees, Volume 2, Alaska Trees and Common Shrubs, 1975.

Willerslev, E., Cappellini, E., Boomsma, W., Nielsen, R., Hebsgaard, M. B., Brand, T. B., Hofreiter, M., Bunce, M., Poinar, H. N., Dahl-Jensen, D., Johnsen, S., Steffensen, J. P., Bennike, O., Schwenninger, J.-L., Nathan, R., Armitage, S., de Hoog, C.-J., Alfimov, V., Christl, M., Beer, J., Muscheler, R., Barker, J., Sharp, M., Penkman, K. E. H., Haile, J., Taberlet, P., Gilbert, M. T. P., Casoli, A., Campani, E., and Collins, M. J.: Ancient Biomolecules from Deep Ice Cores Reveal a Forested Southern Greenland, Science, 317, 111-114, doi:10.1126/science.1141758, 2007.

Woodgate, R. A., Weingartner, T., and Lindsay, R.: The 2007 Bering Strait oceanic heat flux and anomalous Arctic sea-ice retreat, Geophys. Res. Lett., 37, 1-5, doi:10.1029/2009GL041621, 2010.

Yin, Q. Z. and Berger, A.: Individual contribution of insolation and $\mathrm{CO}_{2}$ to the interglacial climates of the past 800,000 years, Clim. Dyn., 38, 709-724, doi:10.1007/s00382-011-1013-5, 2011. 